DOI: $10.15643 /$ libartrus-2015.3.7

\title{
The power of case study method in developing academic skills in teaching Business English (time to play)
}

\author{
(C) E. F. Brattseva*, P. Kovalev \\ National Research University "Higher School of Economics" \\ 17 Promyshlennaya St., 198099 Saint Petersburg, Russia. \\ Phone: +7 (911) 9646459. \\ *Email: elenabrattseva@yandex.ru
}

\begin{abstract}
This article is targeted at analyzing the advantages of using the case study method in the course of Business English at Scientific Research University - Higher School of Economics in Saint Petersburg. Cases offer a lot of opportunities for developing academic skills in reading, writing, listening and making presentations. Students get not only linguistic skills but also non-linguistic competences. Students are taught to work in teams, to analyze the data given in the task, to make decisions. Communicative and managerial skills are obtained as well. Special attention is paid to making team presentations. It is vital to mention that analysis and case solving can be compared to a play where students are actors trying to come up with a solution of a problem using the information given. This approach stimulates students to be more creative, decisive, communicative and goal-oriented. This method helps to achieve better results in developing academic skills while studying Business English. In this article, the importance of Russian companies' problems analyses is pushed forward.
\end{abstract}

Keywords: case study method, academic, skills, development, significant, team presentation, communication, managerial skills, team discussion.

Case-study method in teaching Business English and English for Specific Purposes has been used since 1967 when Strauss and Glazer created their ground theory. Jendrych (2014) mentioned that in the mid-70s of the $20^{\text {th }}$ century it was included in the curriculum of business schools. Harvard Business School has been using this method intensively to teach future managers how to solve real-life problems [1].

Wei Wang pays attention to the fact that almost all universities are stepping up reforms to develop new curriculum, adding more communication - related content into the courses they provide with focus on case-based method [2].

The importance of creating authentic business contexts cannot be overwhelmed. According to Sampath et al (2009) case-study method is one of the opportunities to interact with authentic materials in the same way that the learners might have in real life [3].

Numerous attempts have been made to provide a solid grounding for finding the right way of using case-study method affectively. It is difficult to exaggerate an importance of the authors' contribution in this field. Strengths and weaknesses of the method were analyzed in the article of Vissak (2010) [4]. Multiple analysis of types of case studies available to language learners and teachers have been conducted by Daly (2002) [5]. In the works of Dul and Hak (2010) guidelines for case-study research are pointed out. The authors demonstrate the principles of evaluation of case study research and data analysis presentation [6]. 
Different definitions of case study were given by different scholars. For example in the work of Wedawatta et al (2011) case study is documented as an 'empirical inquiry that investigates a contemporary phenomenon within its real-life context, especially when the boundaries between phenomenon and context are not clearly evident'. The authors put emphasis on 'the rational for selecting case study research strategy over other research strategies'. So this method is undoubtedly an essential one when the future career of graduates will be connected with academic activity [7].

Over a considerable period case-study method has been at the heart of numerous discussions by the leading scholars in Europe and the USA as well as in Russia. Such problem areas in teaching BE and ESP as mismatch between the theory that is included in the curriculums and the practice needs of students, the issue of skills that are needed to prepare specialists in managerial field is discussed by a number of Russian scholars, for instance, Akeshova (2013) [8].

According to Brattseva \& Shchemeleva (2007) it is obvious that scientific field of ESP failed to meet the needs of practicing managers. Thus, the problem of inappropriate educational syllabuses has arisen [9]. Shcherbakova (2007) emphasizes that communicative competence in business communication for advanced level students is considered to be essential for managers working in professional sphere [10]. Moreover, Kuzmina (2005) claims that it is very important for future managers to collaborate and communicate with partners in the case of international business communication [11].

The creative approach in teaching foreign languages is the topic of the article by Kiseleva (2006) and Tikhonov (2005) [12,13]. This approach is extremely significant when solving cases. Kashina pays special attention to role-playing the situations in teaching languages [14]. Case-study method gives a lot of opportunities to use role-plays when discussing and presenting and solving cases.

The existing literature mostly focuses on educational approaches which can be successfully used in Europe and the US. Even Russian authors don't pay enough attention to examining situations and problems concerning the performance of companies currently operating in this country.

In our course we try to offer a new light on the specifics of implementing case-study method in teaching BE and ESP at National Research University Higher School of Economics in Saint Petersburg. With the increased focus on developing economy in Russia the country is faced with the necessity to have specialists who are prepared to run business in national companies, to hire professionals able to make decisions, solve problems, evaluate risks. Therefore, to be competent in solving business cases and presenting them is very topical nowadays.That is why using case-study method as a tool of teaching BE and ESP special attention is paid to analysing the work of Russian companies.

So, first of all, case-studies are taken not only from foreign course books (for example, Market Leader or Intelligent Business) where cases given are informing about the problems of not authentic companies. Secondly, it is possible to get a feedback and take into consideration the answers of the professionals which are of high interest and value and can serve as a good material for further discussion and analysing the solutions obtained. Thirdly, in this case using sources with information about running business of authentic Russian companies would be an excellent alternative. One of the possible sources is the magazine 'Sekret Firmy'. The magazine is issued monthly and offers a case to solve and the best and the worst answers of the professionals in the next issue. Fourthly, the opportunity to develop one more skill, the skill of rendering Russian information in English is provided by conducting research connected with the activities of Russian companies. Finally, the competition in making presentations of additional cases was organized at the end of the course. Students worked in 
teams and had an additional opportunity to share responsibility and complete each other in the process of solving cases. And now let us put emphasis on the importance and relevance of the developing academic skills through case-study method.

The word academic has lately become the key word in the concept of teaching English at Higher School of Economics in Saint Petersburg. The teachers of our department pay special attention to developing academic skills in reading, writing, listening and making presentations. On the one hand, academic skills are surely extremely essential. They help students in preparing a lot of tasks while studying. They can be especially useful for those who are going to continue their education in scientific field.

On the other hand, it is obviously not enough to regard that only academic skills are required. Students who are planning to be managers need not only theoretical knowledge and academic skills, they need practical skills. The answer to the question how to find the balance between academic skills and practical skills may be the course "Business English through case studies". This course is about teaching English in the authentic business context. The main aim of this article is to put emphasis on advantages of the case study method as a tool of developing learner's linguistic and non-linguistic competence as well as academic skills strongly needed in their future profession.

Now, when the task is formulated, let us try to give some characteristics of a case study then we will describe the most important steps of solving a case and establish skills which can be developed while through these steps and show the roles of students and teachers in the process and, finally, we would try to give some advice how to succeed in making team presentations.

First of all, it is necessary to mention that we are considering mini-cases (2-3 pages long), then it should be taken into consideration that students prefer cases presenting problems that have appeared recently.

Next, the structure of a case may vary but the protagonist is always the same: a problem in a company (the problem method).

The possible methodologies of doing cases in the framework of teaching Business English vary but usually the following steps are included:

- examining the case, analyzing and discussing the statistics and data;

- identifying the problem;

- formulating potential threats;

- suggesting and discussing possible variants of solving the problem and choosing the best solution;

- putting the staff in the picture of solutions made (in a written way or presenting the results of the case study in the classroom).

These steps can be identified with developing such skills as reading, speaking, making presentations, listening, writing. When the final decision is taken, all students are requested to use the information in a written form. It may be a letter, a memo, an action plan, a report, an e-mail or guidelines any kind of business writing which best suits the situation, so writing skills are improved greatly.

We would like to emphasise the importance of developing public speaking skills. Learners may be asked to present the results of the case study in the classroom. They receive feedback at the end of their presentation and it helps them to improve their presentation and oral communication skills which no doubt will be strongly demanded in future.

And now some words about the roles of teachers and students. Cases are motivating for students since they give them the opportunity to be decision-makers and solve a real life business problem 
(learners are in the role of managers). They have a chance to compete and demonstrate their analytical and managerial skills. They use language naturally, language is a tool to solving a problem. They do tasks relevant to their future professional communication and the teacher is just an observer, mediator and facilitator. Teachers should be encouraged to experiment and use cases as input materials that are alive in class - modified, changed and exploited in various ways.

When speaking about developing academic skills through working with cases, it is necessary to point out the significance of key presentation making skills. It is the final stage in the case study process. Students will face the necessity to inform the staff about the solutions made and discuss possible variants of achieving the best results. Zanina (2010), Brattseva (2009), Brock et al (2013), Gurung et al (2014) conclude that it is impossible to overestimate the value of getting the skills of preparing and making presentations [15-18].

It is a widespread consideration that the presentations are significant component of work for business people, and for specialists of various areas of business operation and even for both college undergraduate and graduate students. It is necessary to admit that a substantial number of people feel stressed and uncomfortable being in front of the audience, delivering a speech, answering the questions or entering a discussion, so it would be helpful to give recommendations how to cope with this problem successfully. It is a matter of a widespread occurrence that, when a person hears the word "presentation" it is associated in his mind with a single presenter (solo presentation) rather than with a team presentation.

The ultimate aim in the framework of this article, concerning case studies, is to focus on the team presentations and develop the outline of the points confirming the existing difference between team presentations and solo presentations. Furthermore, this article will attempt to offer the advice on how to bring the team presentation to the advanced level. Firstly, we will try to outline the key points of the clear-cut distinction between team presentations and solo presentations. Secondly, we will cover the questions, which require participants' special attention during the preparation process as well as during the process of the actual presentation. It is the matter of a paramount importance for the participants to be alert about the problems raised in the process of preparing and making team presentations because when solving a case, students work in teams.

Therefore, first of all we should examine the idea of how solo presentations differ from team presentations and to scrutinize the core elements, which are considered as essential components of a team presentation. It is necessary to admit that there are certain steps to be taken during the preparation process, which tend to be common whether a solo presentation or a team presentation is being developed and those are: the choice of the topic, the process of the research, structuring the presentation, creating PowerPoint slides, and practicing. But if to subject each of the abovementioned steps to scrutiny, that will result in defining all the major differences between solo and team presentations.

Choosing roles. It is a matter of a paramount importance to define the roles in the team right from the start. It might simplify the process of setting and applying a certain pattern of switching speakers in the presentation. Choosing roles is especially important in the case when the role play elements are inserted in the presentation. Knowing what kind of role a person is assigned to can help them to establish a necessary behavior, specify his goals in the presentation and, moreover, reduce the feeling of being stressed.

Advice \#1. Choose roles in the team and define them clearly. 
Creating a feeling of a team. It is significant to turn your group of three or more into one team and perform as team; the critical factor proving that this goal was achieved will be the audience having a feeling like they watched one presentation rather than three different ones. It is essentially important to listen to each other during the presentation. If you feel like your partner is loosing the idea, try to support him and pick up the idea and develop it according to the plan. It is a quite common occurrence due to the fact that participants feel stressed, even if they practiced a lot [16, p. 250].

Advice \#2. Turn your group into a team and perform like a team.

Practice. No matter how profound is the knowledge on the topic the team is going to present, how advanced the participants' level of English is, how good the participants are at public speaking, practice is needed. It will help students to define the roles in the team, to develop a certain pattern of the presentation, to create the feeling of a team and what is more important to play out possible force majeure situations and to learn the techniques of stress curtailment.

Advice \# 3. Schedule your practice sessions.

Team intro. The first speaker has to introduce the whole team and give an overview of the presentation, rather than each member of the team will do it by himself. The introduction is a very important part, since it is the only time when you can impress the audience and get the attention drawn to the presentation.

Advice \#4. Work on your Introduction part and rehearse it in order to make impressive and to be able to catch the attention of the audience.

Transitions and In-group interaction. To make your presentation sound as one complete piece it is crucial to include transitions into the presentation. This way all the segments of the speech will be logically connected.

Advice \#5. When developing the presentation think of appropriate transitions and a certain pattern of switching speakers in the presentation (Fig. 1). But be sure to avoid too many "switches", when delivering the speech you or your partners may feel stressed and forget whose turn is next.

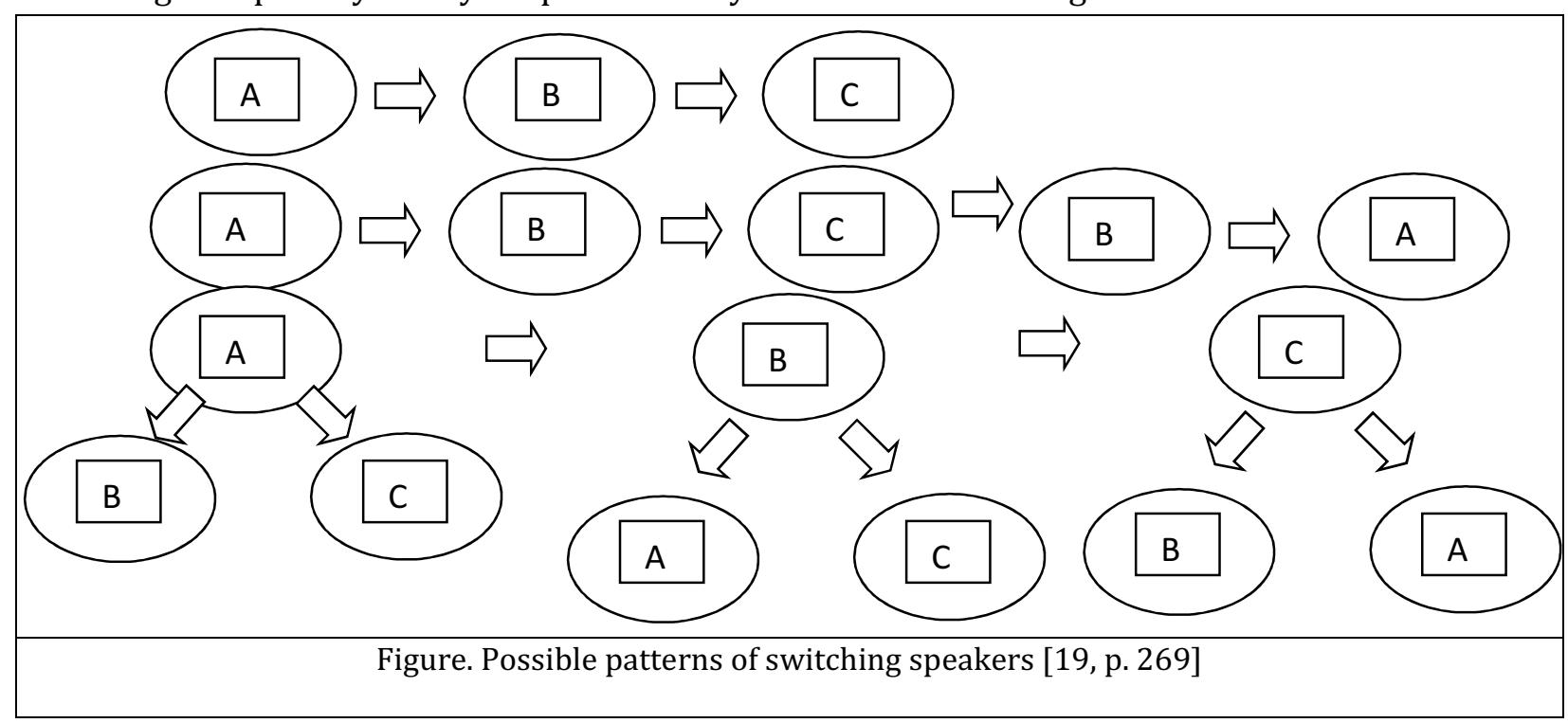

Those are possible patterns of switching speakers during the presentation. The first one is a simple pattern. The second one is a circle pattern. The third one is a matrix pattern. It depends on the team which pattern will be applied; the team may develop their own pattern. 
Internal previews. Each speaker should provide the audience with the short outline of what he is about to present and what was presented in the previous part, so paying attention to so called subconclusions and subintroductions [20, p. 178]. This may be a good tool to prove the logic in the speech and refresh the preview given by the head speaker at the start point, so the audience may follow along.

Advice \#6. Make up several sentences outlining your part of the presentation. Try to keep them short and informative, avoid long and complex sentences.

Group conclusion. The last speaker is responsible to draw the bottom line of the whole presentation and go over all the key points of the speech. It may eliminate some of the questions in the audience if they are missing some of the details of the presentation. Well formulated conclusion may create a clear vision of the core idea of the speech and may result in an additional interest to the topic presented by the team.

Advice \#7. Try to organize the conclusion using short and informative sentences as mentioned in the case of internal previews. Make sure you cover all the key points and underline the core idea, to make sure that the audience got your message.

Move to the front/give a nod of the head. During the presentation non-verbal communication is significant. It can be considered as an instrument to draw the attention of the people in the audience to your performance and keep them focused.

Advice \#8. If you are invited by your colleagues to take the floor and present your part, make a step forward. That will work for the aforementioned simple pattern of the presentation. For the patterns, which are more complex and the "step forward" instrument might not be suitable, use a nod of head instead.

Eye contact with audience and teammates. Eye contact is a significant component of the nonverbal communication as well. It is one of those instruments to establish the rapport with the audience in order to be heard and understood. Since each speaker has limited time to perform eye contact can be considered an element of a paramount importance.

Advice \#9. During the presentation try to maintain the eye contact with your teammates, if all of you are involved in the conversation (i.e. in a role play situation) or at the transition point and try to maintain the eye contact with the audience, when delivering the speech.

Space logistics. Presentations may be held at a different venue and each time the rooms or conference halls are different, some of them may be spacious and some relatively small, all of them had different characteristics of acoustics etc. Therefore, at each new place students had to pick different positions for the team to stand. The location of the team in the room can really affect the perception of the speech delivered.

Advice \#10. When you get to the venue of the contest, have a quick glance at the place you are about to present at and discuss with your team where should each member stand and how can you switch positions if it is necessary during the presentation.

To sum up, from the information given above it is completely obvious that thorough preparation and numerous rehearsals are required to make a perfect presentation.

In conclusion, it can be stated that the case study method offers many opportunities both for teachers and students.

Learners practice a lot of language skills and at the same time develop the analytical managerial and interpersonal skills important in business communication and their further profession. Business English teaching should be an integration of three fields - business knowledge, business discourse and business practice. Case based study serves as a good example of how to integrate these three aspects. 


\section{REFERENCES}

1. Jendrych E. Case Studies in Business English Teaching. International conference "The future of Education". Poland, 2014. URL: http://conference.pixelonline.net/edu_future/common/download/Abstract_pdf/pdf/ITL33-Jendrych.pdf

2. Wang W. The Asian ESP Journal. 2011. Vol. 7. Is. 1. Pp. 97-117.

3. Sampath D., Zalipour A. Proceedings of the 2nd International Conference of Teaching and Learning. INTI University College, Malaysia, 2009.

4. Vissak T. The Qualitative Report. 2010. Vol. 15. No. 2. Pp. 370-388.

5. Daly P. The Internet TESL Journal. 2002. Vol. 8. No. 11.

6. Dul J., Hak T. Case Study Methodology in Business Research. Kindle Edition, 2007.

7. Wedawatta G., Ingirige M., Amaratunga R. ARCOM doctoral workshop, International conference on building resilience. Kandalama, Sri Lanka, 2011.

8. Akeshova N. M. The use of case study method in teaching foreign language. International Kazakh-Turkish University, Kazakhstan, 2013.

9. Brattseva E. F., Shchemeleva I. Yu. Diskussionnyi klub FLT: Innovatsionnye proekty v yazykovom obrazovanii. Ed. Yu. B. Kuz'menkovoi. Moscow: Izd-vo GU VShE, 2007. No. 6. Pp. 220-224.

10. Shcherbakova O. Yu. Diskussionnyi klub FLT: Innovatsionnye proekty v yazykovom obrazovanii. Ed. Yu. B. Kuz'menkovoi. Moscow: Izd-vo GU VShE, 2007. No. 6. Pp. 229-233.

11. Kuz'mina E. V. Diskussionnyi klub FLT: Innovatsionnye proekty v yazykovom obrazovanii. Ed. Yu. B. Kuz'menkovoi. Moscow: Izd-vo GU VShE, 2007. No. 6. Pp. 182-187.

12. Kiseleva Z. A. Problemy filologii i metodiki prepodavaniya inostrannykh yazykov: sb.nauch.statei. Ed. V. A. Yamshanovoi. Saint Petersburg: Izd-vo SPbGUEF, 2006. No. 7. Pp. 35-38.

13. Tikhonov S. P. Inostrannye yazyki v ekonomicheskikh vuzakh Rossii. Ed. V. A. Yamshanovoi. Saint Petersburg: Izdvo SPbGUEF, 2005. No. 4. Pp. 88-98.

14. Kashina E. G. Inostrannye yazyki v sisteme poslevuzovskogo i dopolnitel'nogo obrazovaniya: Materialy 1-oi Vserossiiskoi nauchno-metodicheskoi konferentsii. Ed. L. V. Polubichenko. Moscow: Izd-vo RGSU, 2005. Pp. 94-104.

15. Zanina E. L. Homo Loquens: aktual'nye voprosy lingvistiki i metodiki prepodavaniya inostrannykh yazykov. Ed. I. Yu. Shchemelevoi. Saint Petersburg: Yutas, 2010. No. 2. Pp. 257-266.

16. Brattseva E. F. Diskussionnyi klub FLT: Sovremennye problemy lingvistiki, teorii i praktiki prepodavaniya inostrannykh yazykov. Ed. Yu. B.Kuz'menkovoi. Moscow: Izd-vo GU VShE, 2009. No. 7. Pp. 249-256.

17. Brock S., Brodahi C. Journal of Information Technology Education. 2013. Vol. 12. Pp. 95-119.

18. Gurung R., Kempen L., Klemm K. Teaching of Psychology. 2014. Vol. 41. No. 4. Pp. 349-353.

19. Brattseva E. F. Homo Loquens: aktual'nye voprosy lingvistiki i metodiki prepodavaniya inostrannykh yazykov. Ed. I. Yu. Shchemelevoi. Saint Petersburg: Yutas, 2010. No. 2. Pp. 266-272.

20. Lucas S. E. The Art of Public Speaking. New York, 2012. Pp. 1-382. 
DOI: $10.15643 /$ libartrus-2015.3.7

\title{
Метод кейс-стади как способ развития академических компетенций
}

\author{
() Е. Ф. Братцева*, А. П. Ковалев \\ Национальный Исследовательский университет «Высшая школа экономики» \\ Россия, 198099 г. Санкт-Петербург, Промышленная ул., 17. \\ Тел.: +7 (911) 9646459. \\ *Email: elenabrattseva@yandex.ru
}

\begin{abstract}
В данной статье рассматриваются основные принципы и технологии использования метода кейсстади на занятиях по деловому английскому языку в Научно-Исследовательском Университете - Высшей Школе Экономики в Санкт-Петербурге. Цель данной работы - продемонстрировать преимущества метода кейс-стади как инструмента развития лингвистической и не лингвистической компетенций учащихся. В статье анализируются возможности, которые дает этот метод для развития академических навыков учащихся, таких как академическое чтение, письмо, аудирование. Такой подход к обучению деловому английскому также способствует развитию практических навыков, необходимых в будущей профессиональной деятельности обучающихся. Особое внимание обращается на развитие способности к подготовке и проведению групповой презентации по результатам работы над кейсом. Сегодня анализ и решение кейсов наряду с умением представить полученные результаты в виде групповой презентации становятся одним из важнейших компонентов как в работе профессионалов, так и в работе студентов. Анализ и решение кейсов - это своего рода драматическая пьеса, в которой актеры - студенты пытаются на основе имеющейся информации найти оптимальное решение проблемы. Такой подход к обучению английскому языку является в высокой степени мотивирующим, что способствует достижению более высокого уровня выполнения поставленной задачи по развитию академических навыков.
\end{abstract}

Ключевые слова: метод кейс-стади, академические навыки, командная презентация, менеджериальные навыки, коммуникационные навыки, взаимодействие внутри команды, деловой английский, мотивация.

Просьба ссылаться на эту работу как: Brattseva E. F., Kovalev P. The power of case study method in developing academic skills in teaching Business English (time to play) // Liberal Arts in Russia. 2015. Vol. 4. No. 3. Pp. 234-242.

\section{ЛИТЕРАТУРА}

1. Jendrych E. Case Studies in Business English Teaching // International conference “The future of Education". Poland, 2014. URL: http://conference.pixelonline.net/edu_future/common/download/Abstract_pdf/pdf/ITL33-Jendrych.pdf

2. Wang W. Teaching Business English in China: Views on the Case-based teaching in Intercultural Business Communication // The Asian ESP Journal. 2011. Vol. 7. Is. 1. Pp. 97-117.

3. Sampath D., Zalipour A. Practical Approaches to the Teaching of Business English // Proceedings of the 2nd International Conference of Teaching and Learning. INTI University College, Malaysia, 2009.

4. Vissak T. Recommendations for Using the Case Study Method in International Business Research // The Qualitative Report. 2010. Vol. 15. No. 2. Pp. 370-388.

5. Daly P. Methodology for Using Case Studies in the Business English Language Classroom // The Internet TESL Journal. 2002. Vol. 8. No. 11.

6. $\quad$ Dul J., Hak T. Case Study Methodology in Business Research. Kindle Edition, 2007. 
7. Wedawatta G., Ingirige M., Amaratunga R. Case study as a research strategy: Investigating extreme weather resilience of construction SMEs in the UK // ARCOM doctoral workshop, International conference on building resilience. Kandalama, Sri Lanka, 2011.

8. Akeshova N. M. The use of case study method in teaching foreign language. International Kazakh-Turkish University, Kazakhstan, 2013.

9. Братцева Е. Ф., Щемелева И. Ю. Обучаем выступать публично (опыт составления программы миникурса) // Дискуссионный клуб FLT: Инновационные проекты в языковом образовании / Под ред. Ю. Б. Кузьменковой. М.: Изд-во ГУ ВШЭ, 2007. Вып. 6. С. 220-224.

10. Щербакова О. Ю. Формирование коммуникативной компетенции в деловом общении на продвинутом этапе обучения ИЯ в неязыковом вузе // Дискуссионный клуб FLT: Инновационные проекты в языковом образовании / Под ред. Ю. Б. Кузьменковой. М.: Изд-во ГУ ВШЭ, 2007. Вып. 6. С. 229-233.

11. Кузьмина Е. В. Формирование навыков и умений реализации коммуникативных задач в профессионально значимых ситуациях иноязычного устноречевого общения // Дискуссионный клуб FLT: Инновационные проекты в языковом образовании / Под ред. Ю. Б. Кузьменковой. М.: Изд-во ГУ ВШЭ, 2007. Вып. 6. С. 182-187.

12. Киселева 3. А. Творческий подход в обучении иностранному языку в экономическом вузе // Проблемы филологии и методики преподавания иностранных языков: сб. науч. статей / Под ред. В. А. Ямшановой. СПб.: Изд-во СПбГУЭФ, 2006. Вып. 7. С. 35-38.

13. Тихонов С. П. Обучение творческому мышлению на занятиях по иностранному языку в вузе // Иностранные языки в экономических вузах России / Под ред. В. А. Ямшановой. СПб.: Изд-во СПбГУЭФ, 2005. №4. С. 88-98.

14. Кашина Е. Г. Театральность профессионально-педагогической деятельности преподавателя иностранного языка // Иностранные языки в системе послевузовского и дополнительного образования: Материалы 1-ой Всероссийской научно-методической конференции / Под ред. Л. В. Полубиченко. М.: Изд-во РГСУ, 2005. C. 94-104.

15. Занина Е. Л. Использование Power Point для создания и проведения презентаций // Ното Loquens: aкmyальные вопросы лингвистики и методики преподавания иностранных языков / Под ред. И. Ю. Щемелевой. СПб.: Ютас, 2010. Вып. 2. С. 257-266.

16. Братцева Е. Ф. Выступать нельзя бояться // Дискуссионный клуб FLT: Современные проблемы лингвистики, теории и практики преподавания иностранных языков / Под ред. Ю. Б.Кузьменковой. М.: Изд-во ГУ ВШЭ, 2009. Вып. 7. С. 249-256.

17. Brock S., Brodahi C. A Tale of Two Cultures: Cross Cultural Comparison in Learning Presentation Software Tool in the US and Norway // Journal of Information Technology Education. 2013. Vol. 12. Pp. 95-119.

18. Gurung R., Kempen L., Klemm K. Dressed to Present: Ratings of Classroom Presentations Vary with Attire // Teaching of Psychology. 2014. Vol. 41. No. 4. Pp. 349-353.

19. Братцева Е. Ф. Как сделать командное выступление успешным // Hoто Loquens: актуальные вопросы лингвистики и методики преподавания иностранных языков / Под ред. И. Ю. Щемелевой. СПб.: Ютас, 2010. Вып. 2. С. 266-272.

20. Lucas S. E. The Art of Public Speaking. New York, 2012. Pp. 1-382. 